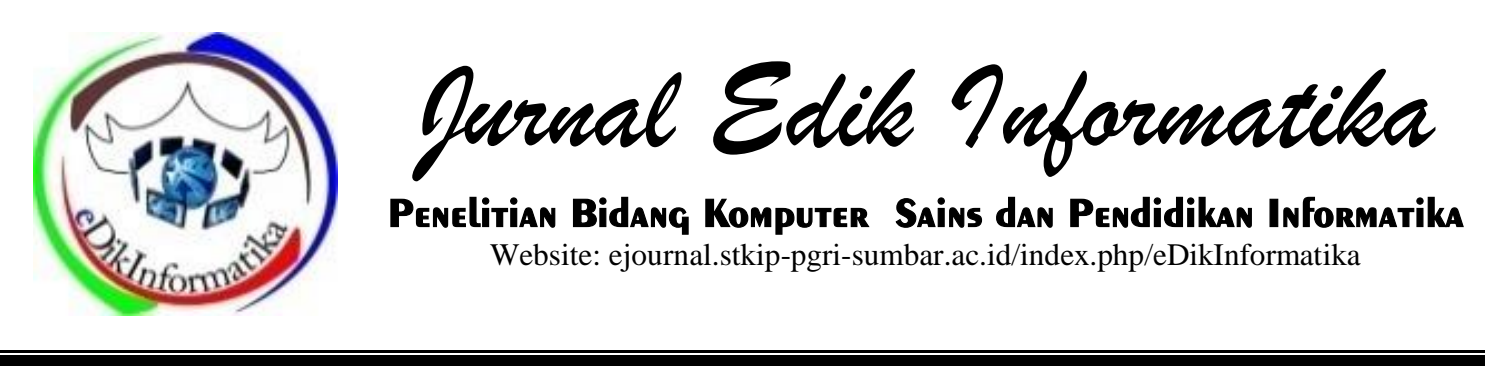

\title{
SISTEM PENDUKUNG KEPUTUSAN PENERIMAAN BEASISWA BERPRESTASI MENGGUNAKAN METODE WEIGTHED PRODUCT (WP) DI SMA NEGERI 1 NAN SABARIS
}

\author{
Neni Mahyuni', Thomson Mary², Ami Anggraini Samudra ${ }^{3}$ \\ ${ }_{1.2}$ STKIP PGRI Sumatera Barat \\ Neniwahyuni0708@gmail.com
}

\begin{tabular}{l} 
INFO ARTIKEL \\
\hline Diterima: \\
17 Oktober 2019 \\
Direview: \\
04 November 2019 \\
Disetujui: \\
10 Desember 2019 \\
\hline Keywords: \\
\hline Decision Support \\
System, Java \\
Desktop, \\
Scholarship, \\
Weighted Product..
\end{tabular}

\begin{abstract}
SMA Negeri 1 nan Sabaris has an outstanding scholarship given to outstanding students and underprivileged students. To determine students who are entitled to receive scholarships, 1 nan Sabaris public schools use the manual method, so it takes time and results that are inaccurate and not on target. The researchers aimed to establish a decision support system to assist officials and schools in selecting students who were eligible to receive scholarships based on their scholarship acceptance criteria at Sabaris 1 nan SMA. The method applied in the decision support system for this discussion uses the Weighted Product (WP) method which uses the Java programming language and the MySQL database as the database. In designing the decision-making system for exceptional scholarship achievement, the authors used the System Development Life Cycle (SDLC) concept such as problem analysis, system design, code writing program, implementation and maintenance testing program. In testing the decision support system built using the Black Box test. From the trial results stated that the decision support system is able to provide students with recommendations for the achievement of outstanding academic knowledge in accordance with established criteria. The conclusion of this study is the creation of a system that can help SMA Negeri 1 nan Sabaris in providing exceptional scholarships according to the scholarship recipient student data.
\end{abstract}

\section{PENDAHULUAN}

Dalam melakukan penyeleksian beasiswa yang ada di SMA Negeri 1 Nan Sabaris, terdapat beberapa kriteria sebagai acuan yaitu nilai rata-rata siswa, kehadiran siswa, penghasilan orang tua, serta tanggungan orang tua. Untuk menentukan siswa yang berhak menerima beasiswa agar mendapatkan hasil yang akurat, cepat dalam pengolah data, serta tepat sasaran maka diperlukan sebuah system pendukung keputusan. 
Sistem pendukung keputusan merupakan bagian dari sistem informasi berbasis terkomputer yang dapat digunakan untuk mendukung pengambilan keputusan(Samudra, 2014:2). Sistem pendukung keputusan adalah proses penelusuran masalah yang berawal dari latar belakang suatu masalah, identifikasi suatu masakah, hingga terbentuknya suatu kesimpulan atau rekomendasi, rekomendasi ini nantinya yang akan digunakan sebagai pedoman dalam pengambilan keputusan (Fahmi, 2016:2). Dengan adanya sistem pendukung keputusan akan dapat membantu dalam pengambilan suatu keputusan dan mempermudah petugas dalam menyelesaikan permasalahan yang ada.

Berdasarkan hasil penelitian yang dilakukan oleh muslihudin sistem pendukung keputusan peneriamaan beasiswa berprestasi menggunakan metode weigthet product (WP), sistem ini dapat menentukan siswa yang berhak menerima beasiswa berprestasi (Muslihudin dan Dewi, 2018:118).

Metode yang di terpakan dalam sistem pendukung keputusan adalah metode weighted product (WP). Metode weighted product(WP) memiliki kemampuan memberi solusi optimal dalam sistem pemeringkatan dan kompleksitas yang tidak terlalu sulit sehingga waktu yang dibutuhkan dalam hasil perhitungan relatif singkat (Basri, 2017:2). Untuk merancang sistem pendukung keputusan bahasa pemrograman yang digunakan adalah java dengan aplikasi NetBeanst, MySQL sebagai basis data, dan XAMPP untuk pengelolaan data base.

\section{METODE PENELITIAN}

\section{Analisis dengan metode Weigthed Product (WP)}

Dalam prosesweigthet product (WP) diperlukan kriteria dan bobot yang akan dijadikan bahan perhitungan dalam menentukan beasiswa berprestasi di SMA Negeri 1 Nan Sabaris. Tabel 1 akan memberi keterangan kriteria peneriman beasiswa berprestasi. Selanjutnya pemberi keputusan memberikan bobot preferensi untuk masing-masing kriteria W (bobot awal) dapat dilihat pada tabel 2 .

Dari keterangan masing-masing kriteria pada tabel 2 akan ditentukan bobotbobotnya yaitu sebagai berikut.

Keterangan:

$\begin{array}{ll}\text { Rendah } & =1 \\ \text { Cukup } & =2 \\ \text { Baik } & =3 \\ \text { Sangat baik } & =4\end{array}$

Untuk menyelesaikan masalah Penerimaan Beasiswa Berprestasi. denganmetode Weighted Product (WP) memiliki langkah-langkah sebagai berikut :

a. Menentukan kode dan ketentuan kriteria yang akan dijadikan acuan dalam pengambilan keputusan seperti pada tabel 3. Pada Tabel 3 terlihat pada tahap ini kita menentukan kode kriteria, ketentuan kriteria, nilai bobot.

b. Dilakukan pembobotan awal pada setiap kriteria yang ada seperti pada tabel 4, 5, 6, 7 .

c. Setelah menentukan kriteria dan bobot, maka dilakukan perbaikan bobot dari bobot awal dengan rumus :

$$
W_{j}=\frac{W_{j}}{\sum W_{j}}
$$

Sumber : Agustin dan hendra (2015 : 180)

Wj merupakan $\mathrm{W}$ index ke $\mathrm{j}$, jadi untuk W1 yaitu 30\%, W2 yaitu 20\%, W3 yaitu $30 \%$, W4 yaitu $20 \%$.

d. Setelah melakukan perbaikan bobot, maka dicari kriteria mana yang bernilai keuntungan dan biaya. Jika bernilai biaya maka nilai atributtersebut negatif dan jika bernilai keuntungan maka atribut tersebuat tetap bernilai (positif). Pada contoh kasus ini atribut yang bernilai biaya adalah (C2 dan C3), sedangkan yang bernilai keuntungan adalah (C1 dan $\mathrm{C} 4)$. 
Tabel 1. Keterangan kriteria beasiswa

\begin{tabular}{clc}
\hline kode & Nama_Kriteria & Nilai_bobot \\
\hline C1 & Nilai rata-rata & $30 \%$ \\
C2 & Kehadiran & $20 \%$ \\
C3 & Penghasilan & $30 \%$ \\
C4 & Tanggungan & $20 \%$ \\
\hline
\end{tabular}

Sumber : SMA Negeri 1 Nan Sabaris.

Tabel 2. Keterangan bobot

\begin{tabular}{ccc}
\hline Kode_kriteria & Bobot & Nilai \\
\hline C1 & Rendah & 1 \\
C2 & Cukup & 2 \\
C3 & Baik & 3 \\
C4 & Sangat baik & 4 \\
\hline
\end{tabular}

Sumber : ( Muslihudin,2018)

Tabel 3. Kode dan ketentuan kriteria

\begin{tabular}{ccc}
\hline Kode kriteria & Nama kriteria & Nilai bobot \\
\hline C1 & Nilai rata-rata & $30 \%$ \\
C2 & Kehadiran & $20 \%$ \\
C3 & Penghasilan & $30 \%$ \\
C4 & Tanggungan & $20 \%$ \\
\hline
\end{tabular}

Sumber : SMA Negeri 1 Nan Sabaris

Tabel 4. Kriteria nilai rata-rata (C1)

\begin{tabular}{ccc}
\hline Kriteria Nili rata-rata $(\mathrm{R})$ & Bobot & Nilai \\
\hline $91-100$ & Sangat baik & 4 \\
$71-80$ & Baik & 3 \\
$50-70$ & Cukup & 2 \\
$<50$ & Rendah & 1 \\
\hline
\end{tabular}

Sumber : SMA Negeri 1 Nan Sabaris.

Tabel 5. Kehadiran (C2)

\begin{tabular}{ccc}
\hline Kriteria Kehadiran $(\mathrm{A})$ & Bobot & Nilai \\
\hline Alpa $<1$ & Sangt baik & 4 \\
Alpa $=1$ & Baik & 3 \\
Alpa $=2$ & Cukup & 2 \\
Alpa $>3$ & Rendah & 1 \\
\hline
\end{tabular}

Sumber : SMA Negeri 1 Nan Sabaris

Tabel 6. Penghasilan Orang Tua (C3)

\begin{tabular}{ccc}
\hline Penghasilan $(\mathrm{X})$ & Bobot & Nilai \\
\hline $\mathrm{X} \leq$ Rp. 1.000 .000 & Sangat baik & 4 \\
Rp. $1.000 .000<\mathrm{X} \geq$ Rp. 3.000 .000 & Baik & 3 \\
Rp. $3.000 .000<\mathrm{X} \geq$ Rp. 5.000 .000 & Cukup & 2 \\
$\mathrm{X}>5.000 .000$ & Rendah & 1 \\
\hline
\end{tabular}


Tabel 7. Tanggungan orang tua (C4)

\begin{tabular}{ccc}
\hline Jumlah tanggungan $(\mathrm{T})$ & Bobot & Nilai \\
\hline 1 Anak & Rendah & 1 \\
2 Anak & Cukup & 2 \\
3 Anak & Baik & 3 \\
$\geq 4$ Anak & Sangat baik & 4 \\
\hline
\end{tabular}

Sumber : SMA Negeri 1 Nan Sabaris

Tabel 8. Alternatif dan Kriteria

\begin{tabular}{ccccc}
\hline \multirow{2}{*}{ Alternatif } & \multicolumn{3}{c}{ Kriteria } \\
& C1 & C2 & C3 & C4 \\
\hline A1 & 4 & 2 & 2 & 4 \\
A2 & 3 & 2 & 4 & 4 \\
A3 & 3 & 3 & 3 & 3 \\
A4 & 4 & 2 & 1 & 4 \\
\hline
\end{tabular}

Sumber : SMA Negeri 1 Nan Sabaris

e. Kemudian tahapan selanjutnya melakukan perhitungan Vektor (S). Langkah pertama yaitu menentukan alternatifnya (Tabel 8) dengan nilai kriteria yang sudah ditentukan, adapun alternatif yang akan diteliti yaitu:
A1 $=$ Agusman
A2 $=$ Adrian
A3 = Salsa
A4= Tasya

Langkah selanjutnya adalalah menentukan nilai Vaktor $\mathrm{S}$ terlebih dahulu. Dengan cara mengalikan data setiap nilai alternatif rating kecocokan yang berpangkat positif dari hasil perbaikan bobot. Data perhitungan manual penentuan nilai Vektor $\mathrm{S}$ dari setiap alternatif dapat dilihat seperti berikut:

$$
S_{i=\prod_{j=1}^{n} X_{i j}^{w j}}
$$

Sumber : Agustin dan hendra (2015: 180).

1. Agusman

$$
\begin{aligned}
& S_{1}=\left(4^{0,3}\right)\left(2^{(-0,2)}\right)\left(2^{(-0,3)}\right)\left(4^{0,2}\right)= \\
& 1,414214
\end{aligned}
$$

2. Adrian

$S_{2}=\left(3^{0,3}\right)\left(2^{(-0,2)}\right)\left(4^{(-0,3)}\right)\left(4^{0,2}\right)=$ 1,053718
3. Salsa

$$
S_{3}=\left(3^{0,3}\right)\left(3^{(-0,2)}\right)\left(3^{(-0,3)}\right)\left(3^{0,2}\right)=1
$$

4. Tasya

$$
\left.S_{4}=\left(4^{0,3}\right)\right)\left(2^{(-0,2)}\right)\left(1^{(-0,3)}\right)\left(4^{0,2}\right)=
$$

1,741101

f. Langkah selanjutnya adalah menentukan nilai Vektor V. Nilai Vektor $\mathrm{V}$ digunakan untuk mendapatkan nilai alternatif tertinggi dari setiap Vektor V. Proses pencarian nilai Vektor $\mathrm{V}$ secara manual dapat dilihat sebagai berikut:

$$
V_{i}=\frac{\prod_{j=1}^{n} X_{i j}^{w j}}{\prod_{j=1}^{n}\left(X_{j}\right)^{w j}}
$$

Sumber : Agustin dan hendra (2015: 180)

1) Agusman

$V_{1}=\frac{1,414214}{5,209033}=0,271493$

2) Adrian

$V_{1}=\frac{1,053718}{5,209033}=0,202287$

3) Salsa

$$
V_{1}=\frac{1}{5,209033}=0,191974
$$

4) Tasya

$V_{1}=\frac{1,741101}{5,209033}=0,334241$ 
Dari pengujian diatas dapat disimpulkan bahwa alternatif siswa yang mendapatkan beasiswa berprstasi dari nilai tertinggi ada pada tabel 9 hasil perhitungan. Dari 4 siswa diperoleh nilai Tasya sebagai nilai tertinggi, disusul Agusman, kemudian adrian dan yang terendah salsa.

Tabel 9. hasil perhitungan Vektor V.

\begin{tabular}{cc}
\hline Nama & Nilai \\
\hline Tasya & 0,334241 \\
Agusman & 0,271493 \\
Adrian & 0,202287 \\
Salsa & 0,191974 \\
\hline
\end{tabular}

Sumber : SMA Negeri 1 Nan Sabaris

\section{Rancangan Sistem}

\section{Rancangan global}

1) Herarchy Plus Iinput-Proces-Output(HIPO)

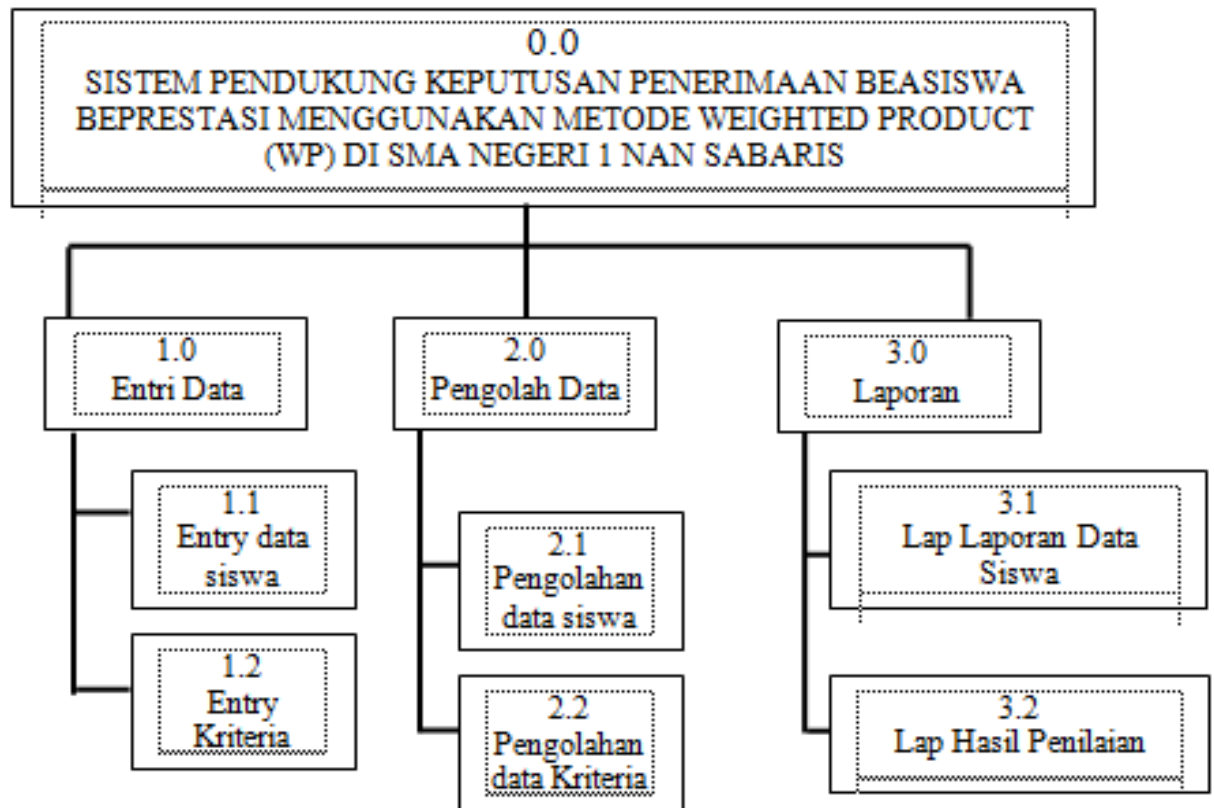

Gambar 1. HIPO Sistem Pendukung Keputusan

Gambar 1 memaparkan bahwasanya dalam Sistem Pendukung Keputusan yang dakan dibangun terdapat tiga proses utama, yaitu 1.0 entri Data, 2.0 Pengolahan data dan 3.0 Laporan atau bisa dikelompokkan mejadi input system, pengolahan data, output.
2) Data Flow Diagram (DFD) level Nol

Data flow diagram menjelaskn tentang alur proses yang masuk kedalam system (data) hingga menghasilkan output berupa informasi. Data flow diagram untuk system pendukung keputusan dapat dilihat pada gambar 2 dan gambar 3 . 


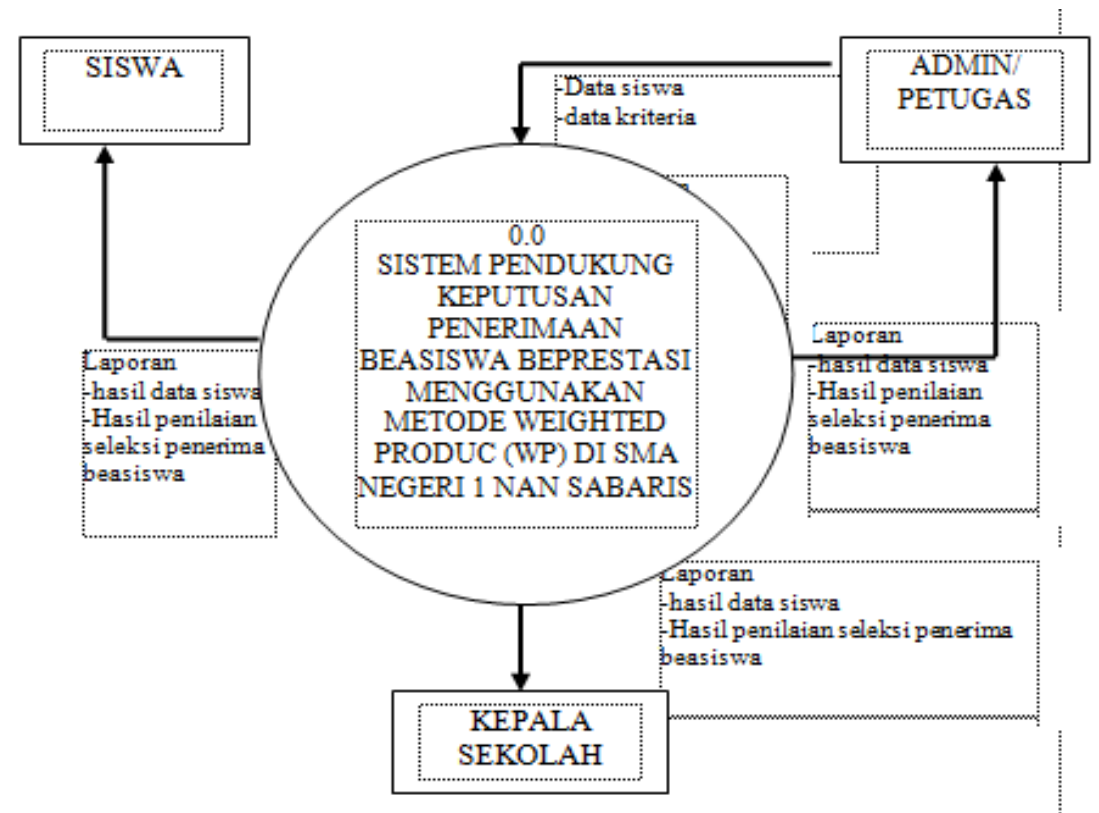

Gambar 2. DFD Sistem PendukungKeputusan Penerimaan Beasiswa Beprestasi Menggunakan Metode Weighted Product (WP)di SMA Negeri 1 Nan Sabaris.

3) Data Flow Diagram (DFD) level 1

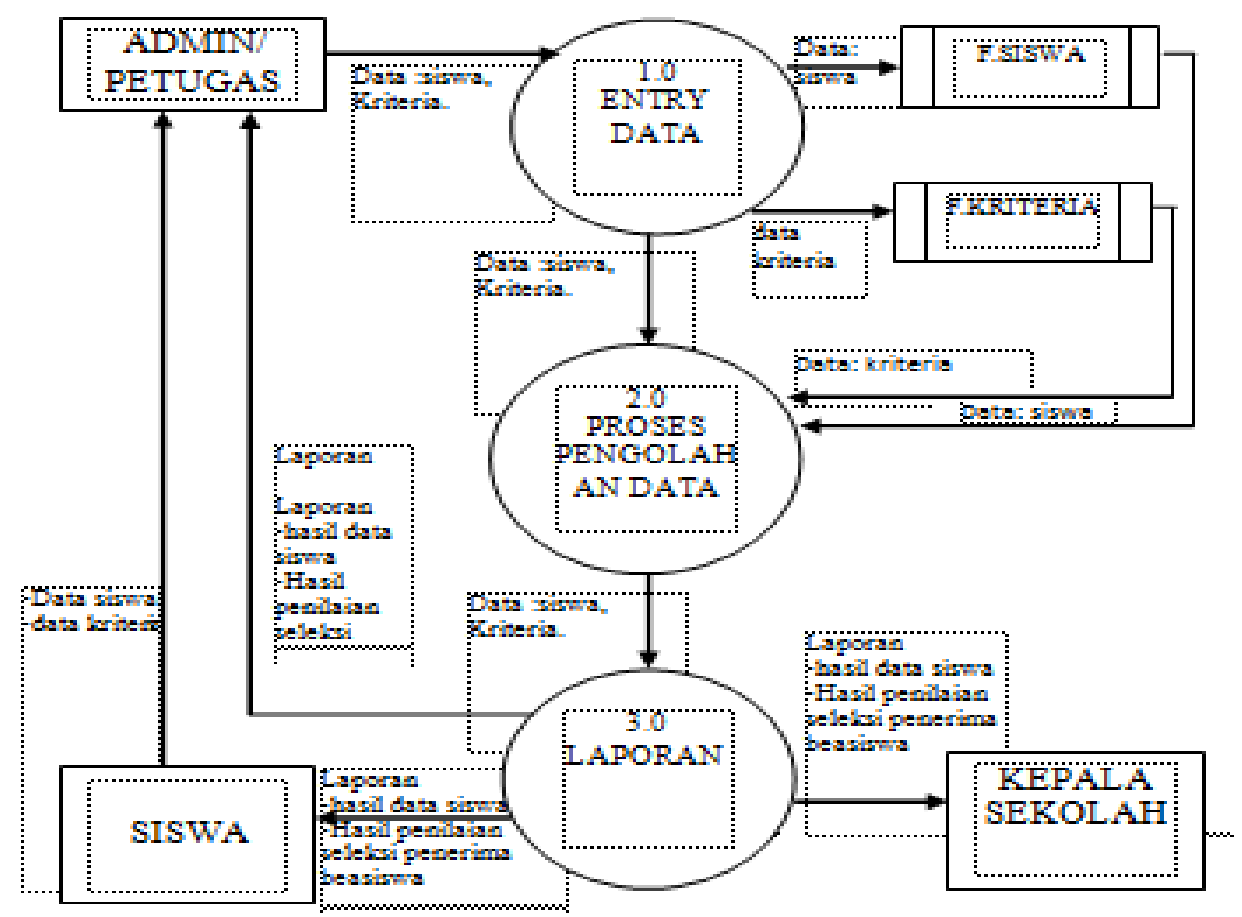

Gambar 3. DFD Level satu Sistem Pendukung Keputusan Penerimaan Beasiswa Beprestasi Menggunakan Metode Weighted Product (WP) di SMA Negeri 1 Nan Sabaris.

4) Entity Relationship Diagram (ERD)

ERD menggambarkan hubungan setiap tabel dengan tabel lainya. Pada database system pendukung keputusan ini terdapat 4 buah tabel dengan beberapa atributnya yang saling berhubungan seperti terlihat pada gambar 4 . 


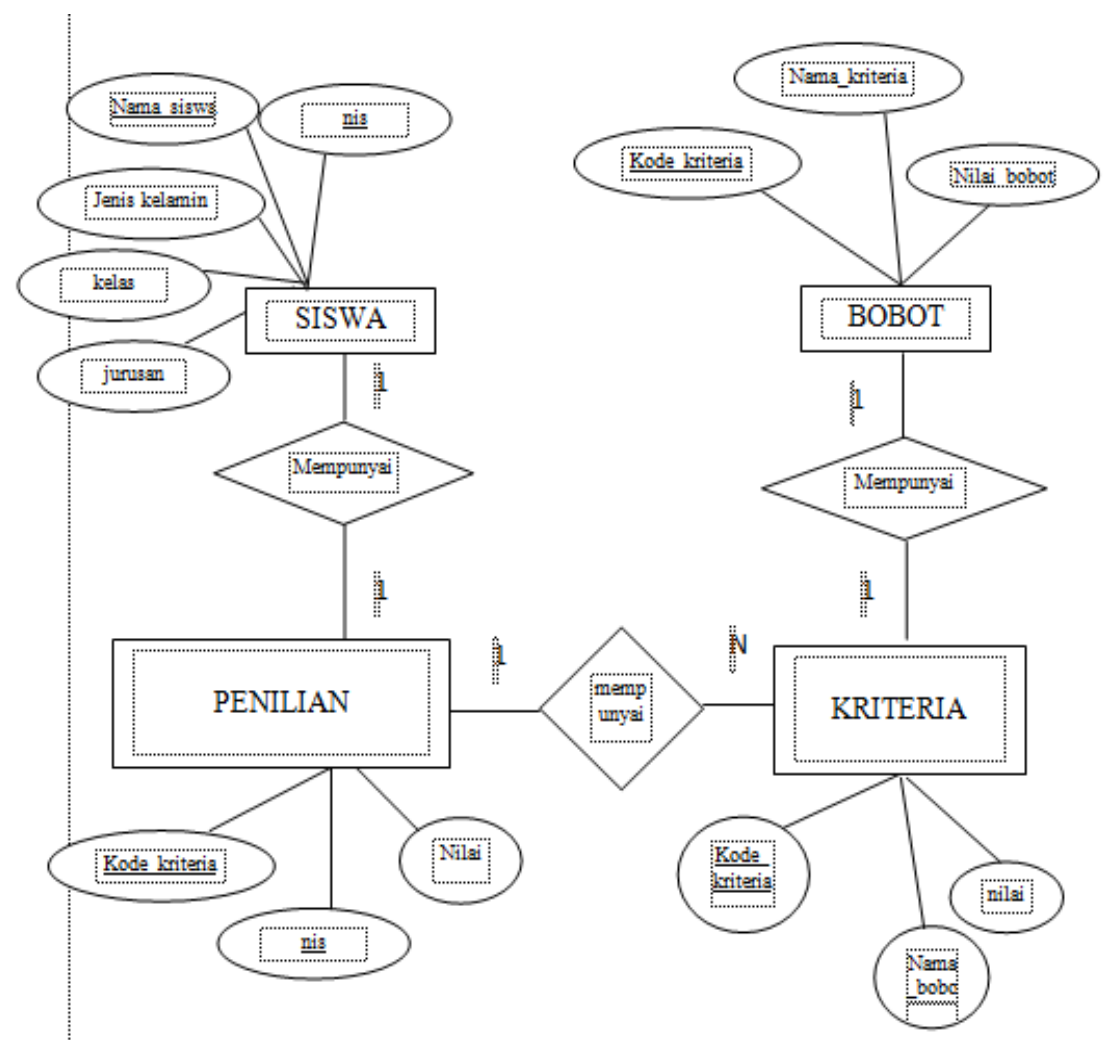

Gambar 4. ERD Sistem Pendukung Keputusan Penerimaan Beasiswa Beprestasi di SMA Negeri 1 Nan Sabaris.

\section{Rancangan Terinci}

1) Struktur menu program

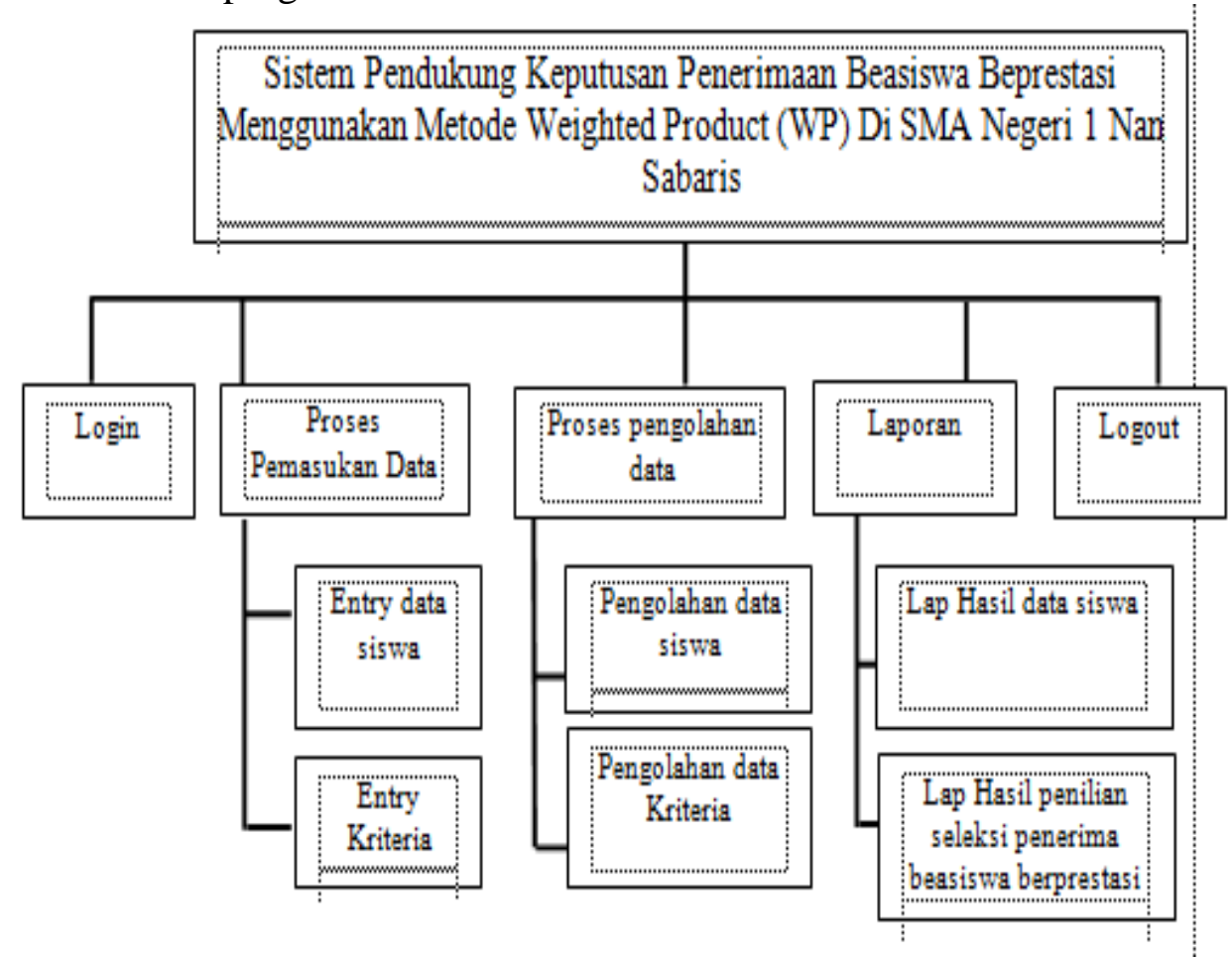

Gambar 5. Struktur Menu Program :Sistem Pendukung Keputusan Penerimaan Beasiswa Beprestasi di SMA Negeri 1 Nan Sabaris. 
2) System Flowchart

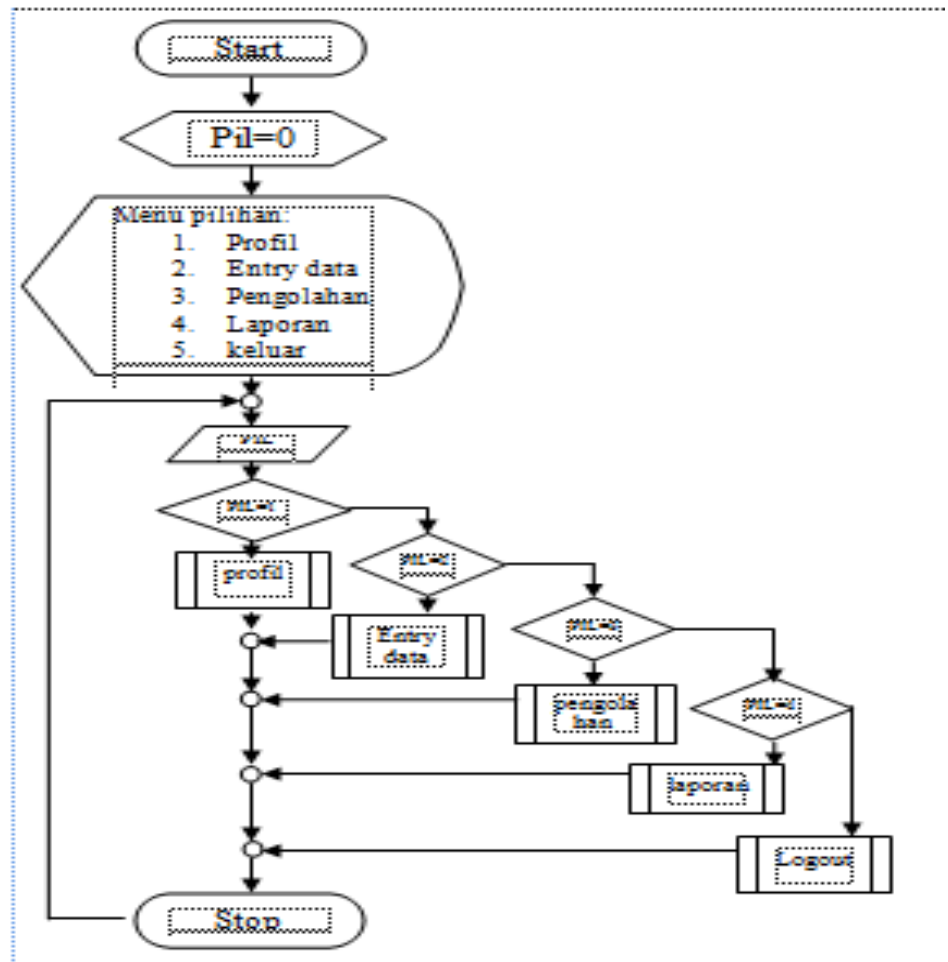

Gambar 6. Flow Chart Struktur Menu Program.

Pada gambar 6 Flow Chart Struktur Menu Program menjelaskan bagaimana proses dari ptuktur menu program/tampilan menu utama sistem. Dimana proses dilakukan dengan mengklik menu start, selanjutnya sistem akan menampilkan beberapa menu, yaitu menu profil, entry data, pengolahan data, lapoan dan logout. Dengan merancang FlowChartakan memudahkan progremer dalam membut sistem, karena mudah untuk dipahami.

\section{HASIL DAN PEMBAHASAN}

1. From menu login

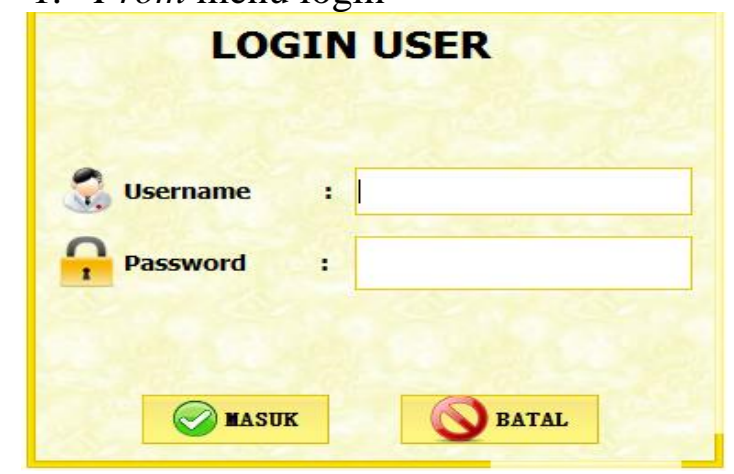

Gambar 7. Form Menu Login.
Form login merupakan form untuk masuk kehalaman utama aplikasi berdasarkan hak akses berupa username dan Password yang telah ditentukan.

\section{Form Menu Utama}

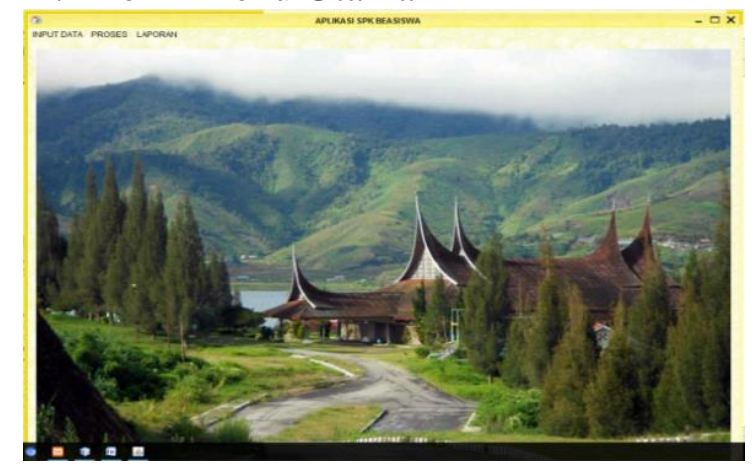

Gambar 8 Form Menu Utama.

Form menu utama merupakan form pilihan menu seperti input data, proses, dan laporan. 
3. Form Input Data Siswa

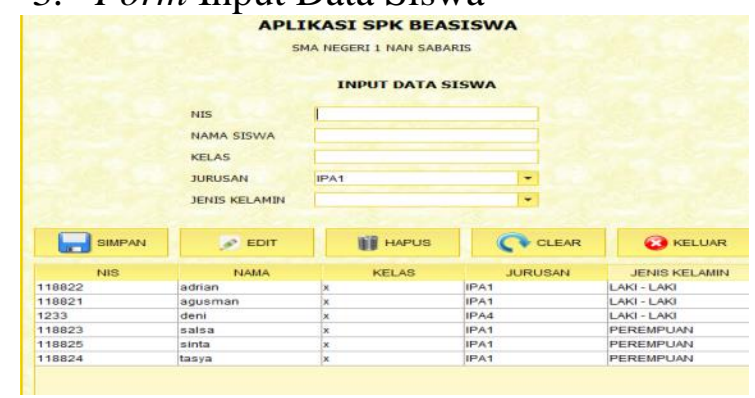

Gambar 9.Input Data Siswa.

From input data siswa merupakan pengisisan data siswa seperti nis, nama, kelas, jurusan, dan jenis kelamin.

\section{Form Input Data Kriteria}

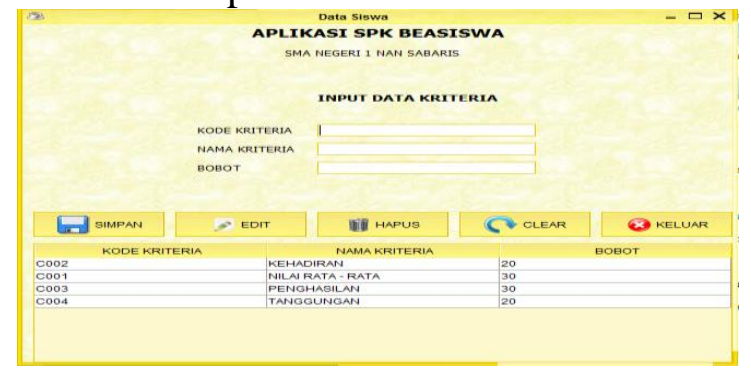

Gambar 10.Input Data Kriteria.

Input data kriteria merupakan pengisian data kriteria seperti kode kriteria, nama kriteria, dan bobot.

\section{From Proses Penilaian}

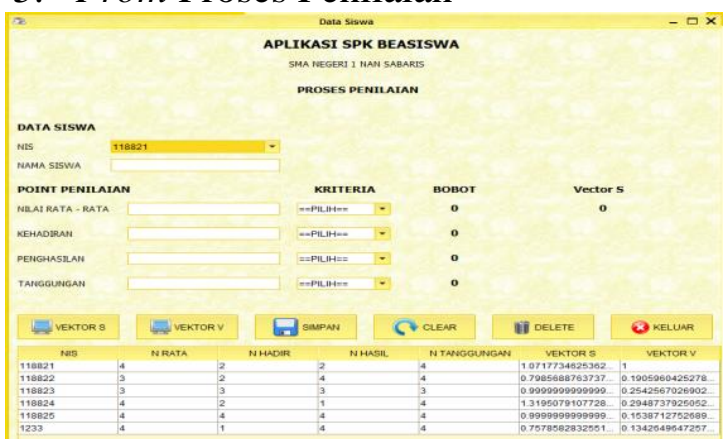

Gambar 11. Form Proses Penilaian.

Form Proses Penilaian merupakan proses pengisian data pada data siswa, poin penilaian dan criteria.

\section{Form Laporan Data Siswa}

Form Laporan Data Siswa merupakan menu laporan dari hasil penginputan data siswa

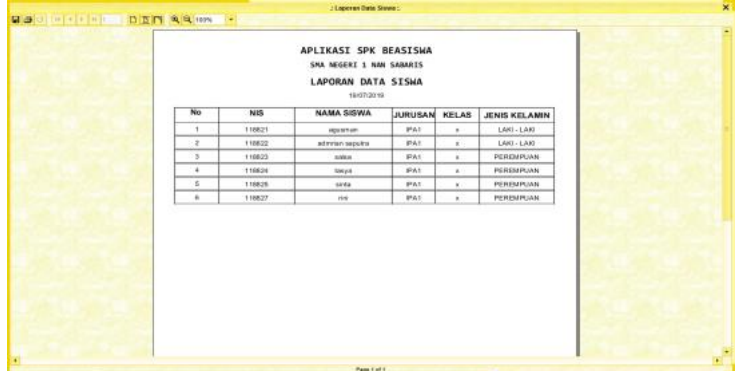

Gambar 12.Laporan Data Siswa.

7. From Laporan Penilaian

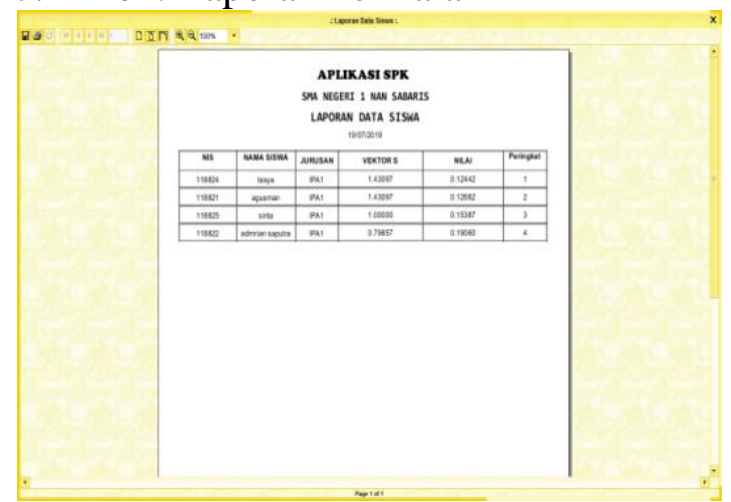

Gambar 13. Laporan Penilaian

Form Laporan Penilaian merupakan menu laporan dari hasil penginputan data proses penilaian.

\section{Aplikasi Sistem Pendukung} Keputusan penerimaan beasiswa berprestasi yang dibuat merupakan sistem pendukung keputusan berbasis dekstop dengan penyimpana basis data.Sistem tersebut diharapkan dapat mengelola data penerimaan beasiswa berprestasi berdasarkan syarat atau kriteria penerimaan beasiswa yang telah ditentukan di SMA Negeri 1 Nan Sabaris. Dengan dibangunnya sistem diharapkan dapat mempermudah dalam proses pengelolaan data nilai dan pelaporan beasiswa berprestasi.

Berdasarkan hasil uji coba Apliksi Sistem Pendukung keputusan yang telah dilaksanakan pada SMA Negeri 1 Nan Sabaris menghasilkan sistem yang dapat mengelola data siswa, data kriteria dan data penilaian serta tersimpan langsung pada database yang telah di sediakan. Selain itu sistem juga dapat mencetak data dan menyimpan data dalam bentuk file. Namun dalam pengujian aplikasi tersebut dapat 
dikatakan belum sempurna dikarenakan masih melakukan beberapa pengujian pada sisi uji saja sehingga masih terdapat beberapa kesalahan dan kekurangan sistem.

\section{KESIMPULAN}

Perancangan dan pembuatan Sistem Pendukung Keputusan Penerimaan Beasiswa Berprestasi Menggunakan Metode Weigthed Product (WP) Di SMA Negeri 1 Nan Sabaris menggunakan metode SDLC yang terdiri analisis, perancangan pengujian dan implementasi. Pada tahap implementasi ini dilakukan dengan membuat aplikasi dengan bahasa pemprograman java dengan aplikasi NetBeans IDE.8.1, XAMPP server dan dapat diambil kesimpulan sebagai berikut

1. Dengan memanfaatkan aplikasi sistem pendukung keputusan penerimaan beasiswa berprestasi proses pengolahan data dapat dilakukan dengan lebih cepat dibandingkan dengan pengolahan data secara manual. Pengolahan data secara manual membutuhkan waktu untuk pencatatan ulang data-data siswa dan pengolahan data beasiswa, sedangkan dengan menggunakan Sistem Pendukung Keputusan ini bisa dilakukan penghematan waktu karena data-data siswa sudah tersimpan pada sisitem dan data beasiswa sudah dikelola oleh sistem.

2. Melalui Sistem Pendukung Keputusan penerimaan beasiswa ini dapat menentukan siswa yang berhak menerima beasiswa dengan menghasilkan nilai tertinggi dan memberi peringkat. Sehingga dapat menentukan siswa mana yang lebih berhak menerima beasiswa tersebut.

3. Sistem Pendukung Keputusan penerimaan beasiswa ini dapat mencetak laporan data siswa dan laporan penilaian beasiswa. Sehingga mempermudah dalam pelaporan sesuai kebutuhan.

Catatan : Artikel ini ditulis berdasarkan Tugas Akhir Neni Mahyuni dengan pembimbing I Thomson Mary, M.Kom dan Pembimbing II Ami Anggraini Samudra, S.Pd, M.Sc

\section{DAFTAR PUSTAKA}

Basri. (2017). Metode Weighted Product (WP) dalam Sistem Pendukung Keputusan Penerimaan Beasiswa Berprestasi. Jurnal Teknik Informatika, 1 .

Dewi, M. M. dan. (2018). Sistem Pendukung Keputusan Penerimaan Beasiswa Berprestasi Menggunakan Metode Weighted Produc. Jurnal TAM, 9 .

Fahmi, S. I. (2016). Menajemen Pengambilan Keputusan Teori dan Aplikasi. bandung: ALFABETAHA.

Samudra, A. A. (2014). Perancangan Sistem Pendukung Keputusan Penyeleksian Beasiswa Menggunakan Metode SAW. Informatika FT Universitas Negeri Padang. 